\title{
ПРОДУКТИВНІСТЬ ТА ЯКІСТЬ ЗЕРНА ПШЕНИЦІ ОЗИМОЇ ЗАЛЕЖНО ВІД ПОЗАКОРЕНЕВОГО ПІДЖИВЛЕННЯ В ЛІВОБЕРЕЖНОМУ ЛІСОСТЕПУ УКРАЇНИ
}

\author{
ЯмкОВИй В.Ю. - кандидат сільськогосподарських наук \\ http://orcid.org/0000-0001-9107-2250 \\ ТОВ «Український Аграрний Ресурс» \\ БУняк О.І. - кандидат сільськогосподарських наук \\ http://orcid.org/0000-0003-4979-9645 \\ Носівська селекційно-дослідна станція \\ Миронівського інституту пшениці імені В.М. Ремесла \\ Національної академії аграрних наук України \\ ящУк Н.О. - кандидат сільськогосподарських наук \\ http://orcid.org/0000-0002-5819-2813 \\ Національний університет біоресурсів і природокористування України
}

Постановка проблеми. Збільшення виробництва високоякісного зерна в Україні залишається одним із найважливіших завдань сільськогосподарського виробництва. Основною зерновою культурою, яка займає біля 45\% посівних площ зернових культур і забезпечує понад $50 \%$ валових зборів зерна в нашій державі, є пшениця озима [1;2].

Нині потенційні можливості сучасних сортів цієї культури коливаються в межах 10-15 т/га, проте середня врожайність зерна в Україні складає 3,5-4,5 т/га, а зерно має переважно низьку якість, яка, на жаль, не завжди відповідає вимогам харчової промисловості [4; 5; 10].

Аналіз останніх досліджень і публікацій. До важливих умов отримання стабільно високих показників урожайності зерна та його якості належить оптимізація живлення рослин [3]. Відомо, що для нормального розвитку рослин необхідні не тільки азот, фосфор, калій, але й мікроелементи, які беруть участь у всіх фрізіологічних процесах росту та розвитку рослин, а також підвищують ефективність багатьох ферментів і покращують засвоєння рослинами елементів живлення з ґрунту [6].

Пшениця характеризується високою чутливістю до застосування мікроелементів [7] зокрема міді та марганцю, що відіграють важливу роль у процесах фотосинтезу, дихання, синтезі білків, утворенні хлорофілу та засвоєнні азоту. Нестача цих мікроелементів у посівах пшениці озимої особливо відчувається у фразі кущіння та на початку виходу рослин у трубку [17].

Найкращим методом забезпечення рослин пшениці озимої марганцем та міддю є позакореневе підживлення [15]. Широко відомо, що найбільш ефективною формою внесення цих мікроелементів $€$ хелатна, засвоюваність якої у кілька разів вище, ніж звичайних солей $[9 ; 11 ; 14]$ Щодо ефективності застосування хелату міді та марганцю в лівобережному Лісостепу України під пшеницю озиму, то це питання вивчене недостатньо, є лише фрагментарні дані $[8 ; 12 ; 13 ; 16]$.

Мета статті полягає у виявленні впливу позакореневого підживлення хелатними мікродобривами на формування врожайності та якості зерна пшениці озимої.

Матеріали та методика досліджень. Дослідження були проведені в умовах лівобережного Лісостепу України на базі Носівської селекційно-дослідної станції Миронівського інституту пшениці імені В.М. Ремесла у виробничій сівозміні впродовж 2019-2020 рр.

Ґрунтовий покрив дослідних ділянок - чорнозем глибокий малогумусний вилугуваний легкосуглинковий, який в орному шарі 0-30 см містить 7,4 мг гідролізованого азоту за Корнфілдом, 14,6 мг рухомих форм фосфору за Чиріковим та 8,3 мг/100 г ґрунту обмінного калію, рН сольової витяжки становить 5,0.

Схема досліду:

1) без позакореневого підживлення (контроль);

2) «РОСТОК» Макро (3 л/га);

3) «РОСТОК» Макро (2 л/га) + «РОСТОК» Мідь (1 л/га);

4) «РОСТОК» Макро (2 л/га) + «РОСТОК» Марганець (1 л/га).

Позакореневе підживлення посівів хелатними мікродобривами проводили на початку відновлення весняної вегетації та на початку виходу рослин пшениці озимої у трубку.

Характеристика мікродобрив «УАРОСТОК» ${ }^{\circledR}$ наведена в табл. 1.

Досліди закладені на насіннєвих посівах пшениці м'якої озимої сорту Оберіг Миронівський, попередником якої було просо. Насіння культури висівали в оптимальні для цієї зони строки. Збір урожаю здійснювали за настання біологічної стиглості окремо за варіантами прямим комбайнуванням. Вміст білка і вологість зерна визначали за методом інфрачервоної

Таблиця 1 - Характеристика мікродобрив «УАРОСТОК» ${ }^{\circledR}$ для позакореневого підживлення, г/л

\begin{tabular}{|l|c|c|c|c|c|c|c|c|c|c|c|}
\hline \multicolumn{1}{|c|}{ Добриво } & $\mathbf{N}$ & $\mathbf{P}_{\mathbf{2}} \mathbf{O}_{\mathbf{5}}$ & $\mathbf{K}_{\mathbf{2}} \mathbf{O}$ & $\mathbf{M g O}$ & $\mathbf{S O}_{3}$ & $\mathbf{F e}$ & $\mathbf{M n}$ & $\mathbf{B}$ & $\mathbf{Z n}$ & $\mathbf{C u}$ & $\mathbf{M o}$ \\
\hline «РОСТОК» Макро & 60 & 120 & 60 & 0,2 & 10 & 1,4 & 1 & 0,2 & 2,2 & 2,5 & 0,05 \\
\hline «РОСТОК» Мідь & - & - & - & - & - & - & - & - & - & 75 & - \\
\hline «РОСТОК» Марганець & - & - & - & - & - & - & 100 & - & - & - & - \\
\hline
\end{tabular}


спектроскопії (ДСТУ 4117:2007), склоподібність за зрізом (ГОСТ 10987-76), вміст сирої клейковини та якість клейковини ручним способом (ДСТУ ISO 21415-1:2009) у лабораторії кафедри технології зберігання, переробки та стандартизації продукції рослинництва ім. проф. Б.В. Лесика (НУБІП України, м. Київ). Математичну обробку даних проводили методом дисперсійного аналізу за Б.О. Доспєховим [18] з використанням табличного редактора Microsoft Office Excel, Agrostat.

Результати досліджень. Вагому роль у формуванні врожаю пшениці озимої відіграють такі показники, як кількість зерен у колосі, маса зерна з одного колоса та маса 1000 зерен. Проведені дослідження виявили, що позакореневе підживлення мікродобривами позитивно вплинуло на структурні показники врожайності (табл. 2).

Так, якщо на контрольному варіанті у колосі налічували 16,9 зерен, то проведення позакореневого підживлення комплексним добривом «РОСТОК» Макро в доз 3 л/га забезпечило збільшення зазначеного показника на 3,9 зерен. Проте зменшення дози внесення комплексного мікродобрива «РОСТОК» Макро на 1 л/га та додавання до бакової суміші добрива «РОСТОК» Марганець в дозі 1 л/га збільшували цей показник лише на 3,3 зерен. Найбільша кількість зерен у колосі була сформована у варіанті підживлення «РОСТОК» Макро (2 л/га) + «РОСТОК» Мідь (1 л/га) і становила 22,2 шт.

Науковцями [19; 20; 21] було встановлено, що маса зерна з колосу істотно змінюється залежно від режиму живлення. В наших дослідженнях під час поліпшення поживного режиму за рахунок проведення позакореневого підживлення було збільшення в рослин маси зерна з колосу на 31-34\% порівняно з контрольним варіантом.

Так, на контрольному варіанті маса зерна з 1 колоса становила 0,70 г. За позакореневого підживлення добривом «РОСТОК» Макро в дозі 3 л/га маса зерна з 1 колоса зросла до 0,92 г. Найвищою маса зерна з 1 колоса спостерігалася у варіанті позакореневого підживлення «РОСТОК» Макро (2 л/га) + «РОСТОК» Мідь (1 л/га) і становила 1,03 г.
Також важливим технологічним показником якості зерна є маса 1000 зерен. Він характеризує виповненість зерна та його розміри. У наших дослідженнях показник маси 1000 зерен коливався від 41,3 до 46,2 г.

Найменша маса 1000 зерен була на контрольному варіанті, а саме 41,3 г, позакореневе підживлення рослин пшениці озимої добривом «РОСТОК» Макро супроводжувалося збільшенням цього показника на 3,1 г. У варіантах з підживленнями «РОСТОК» Макро (2 л/га) + «РОСТОК» Марганець (1 л/га) та «РОСТОК» Макро (2 л/га) + «РОСТОК» Мідь (1 л/га) маса 1000 зерен зростала на 4,6 г і 4,9 г відповідно

Урожайність $є$ основним показником ефективності розроблених та впроваджених прийомів технології вирощування. Отримані дані урожайності свідчать про те, що позакореневе підживлення хелатними добривами істотно впливало на врожайність пшениці озимої $\left(\mathrm{HIP}_{05}=0,31 \mathrm{t} /\right.$ га) (табл. 3).

Встановлено, що урожайність зерна пшениці озимої за проведення позакореневого підживлення рослин мікродобривами зростала від 0,36 до 0,62 т/га, або на 9,7-16,8\%.

Згідно з отриманими даними, найменший приріст врожайності зерна був у варіанті підживлення «РОСТОК» Макро (3 л/га), а саме 0,36 т/га, найвищий приріст урожайності, а саме 0,62 т/га, отримано у варіанті позакореневого підживлення «РОСТОК» Макро (2 л/га) + «РОСТОК» Мідь (1 л/га).

Поліпшення умов живлення за рахунок проведення позакореневого підживлення позначалося на показниках якості зерна. Слід відзначити, що вологість зерна на всіх досліджуваних варіантах була нижче критичного показника (14\%) і коливалась у межах 11,9-12,4\%. Досліджуваний показник лише дещо варіювався залежно від варіанта підживлення мікродобривами, що пов'язано зі вмістом білкових речовин. Чим більше вміст білка, тим більше вологи може безпечно утримувати зерно пшениці. Таким чином, зростання вмісту білка на варіантах позакореневого підживлення посівів пшениці озимої дає змогу безпечно зберігати зерно за дещо вищої вологості.

Таблиця 2 - Показники структури врожайності пшениці озимої залежно від позакореневого підживлення мікродобривами (середнє за 2019-2020 рр.)

\begin{tabular}{|l|c|c|c|}
\hline \multirow{2}{*}{ Варіанти досліду } & \multicolumn{3}{c|}{ Показники структури } \\
\cline { 2 - 4 } & $\begin{array}{c}\text { Кількість зерен } \\
\text { у колосі, шт. }\end{array}$ & $\begin{array}{c}\text { Маса зерна } \\
\text { 3 колосу, } \mathbf{~}\end{array}$ & $\begin{array}{c}\text { Маса } \\
\mathbf{1 ~ 0 0 0 ~ з е р е н , ~} \mathbf{~}\end{array}$ \\
\hline Без позакореневого підживлення (контроль) & 16,9 & 0,70 & 41,3 \\
\hline «РОСТОК» Макро (3 л/га) & 20,8 & 0,92 & 44,4 \\
\hline «РОСТОК» Макро (2 л/га) + «РОСТОК» Мідь (1 л/га) & 22,2 & 1,03 & 46,2 \\
\hline «РОСТОК» Макро (2 л/га) + «РОСТОК» Марганець (1 л/га) & 20,2 & 0,93 & 45,9 \\
\hline $\mathrm{HIP}_{0,5}$ & 1,12 & 0,09 & 1,01 \\
\hline
\end{tabular}

Таблиця 3 - Урожайність пшениці озимої залежно від позакореневого підживлення мікродобривами (середнє за 2019-2020 рр.), т/га

\begin{tabular}{|l|c|}
\hline \multicolumn{1}{|c|}{ Варіанти досліду } & Урожайність, т/га \\
\hline Без позакореневого підживлення (контроль) & 3,69 \\
\hline «РОСТОК» Макро (3 л/га) & 4,05 \\
\hline «РОСТОК» Макро (2 л/га) + «РОСТОК» Мідь (1 л/га) & 4,31 \\
\hline «РСТОка & 0,36 \\
\hline $\mathrm{HIP}_{05}$ & 4,14 \\
\hline
\end{tabular}


Важливим фрізичним показником зерна пшениці озимої $€$ склоподібність. Вона характеризує білково-крохмальний комплекс зерна, чим надає початкову інформацію про можливість використання пшениці для задоволення харчових чи технічних цілей.

Так, контрольний варіант (без позакореневого підживлення) характеризувався низькими показниками склоподібності (26\%), що не дає змоги використовувати зерно пшениці цього варіанта для виробництва якісного борошна та хлібобулочних виробів (рис. 1).

Позакореневі підживлення мікродобривами сприяли суттєвому збільшенню цього показника (від 14\% до 47\% залежно від варіанта), що привело до зростання якості зерна пшениці та можливості отримувати якісне борошно для хлібопечення.

Найбільше зростання склоподібності відзначено у варіанті підживлення «РОСТОК» Макро (2 л/га) + «РОСТОК» Мідь (1 л/га), а саме на $47 \%$, дещо менше у варіанті позакореневого підживлення добривом «РОСТОК» Макро в дозі 3 л/га, а саме на 31\% порівняно з контролем. За показником склоподібності зерно, отримане за цих двох варіантах, відповідає першому класу якості. У варіанті позакореневого підживлення рослин за схемою «РОСТОК» Макро (2 л/га) + «РОСТОК» Марганець (1 л/га) відбулося значно менше зростання досліджуваного показника: лише на $14 \%$ та відповідно до другого класу якості.

Дисперсійний аналіз виявив статистично значущий вплив зміни показника склоподібності залежно від варіантів позакореневого підживлення мікродобривами: $\mathrm{Fp}=1006,62>$ Fкрит $=6,59$.

Один із найвагоміших технологічних показників, який нормується і в наших, і в міжнародних стандартах, - це вміст білка. У контрольному варіанті цей показник був не надто високим, а зерно пшениці, отримане за цього варіанта, відповідало третьому класу якості (рис. 2).

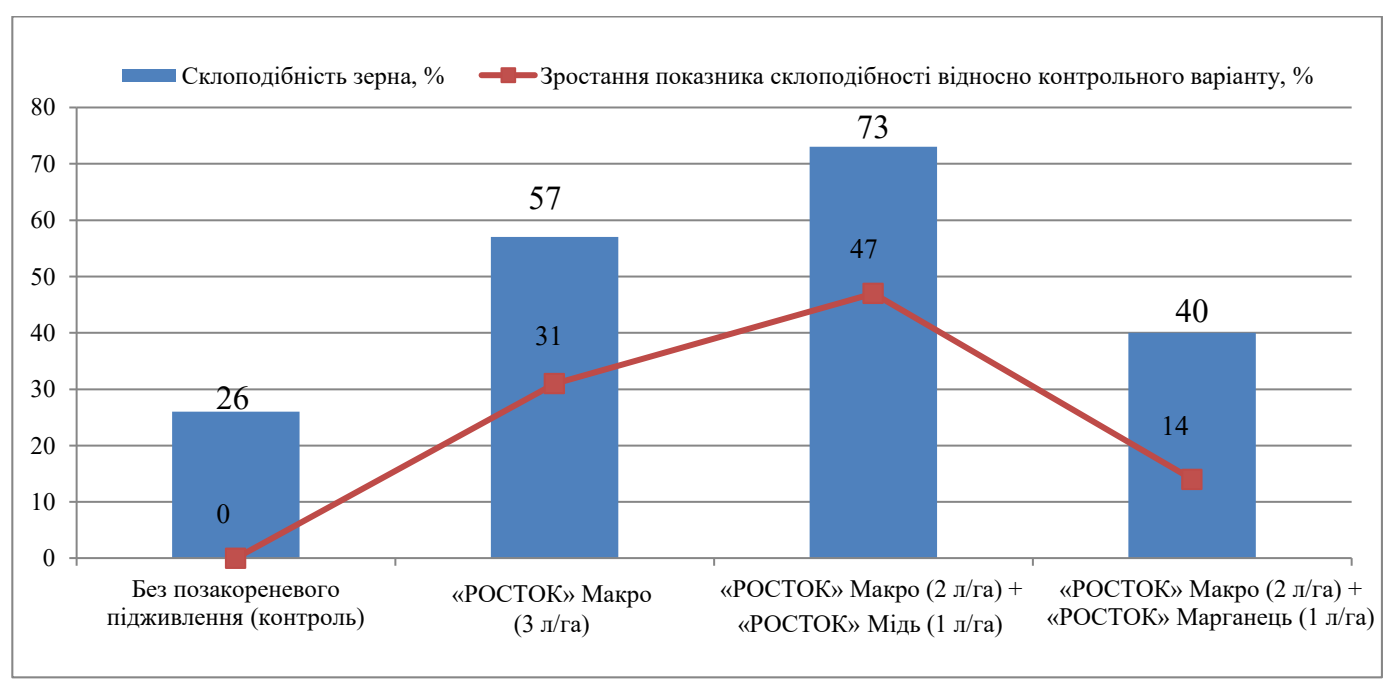

Puс. 1. Зміна склоподібності зерна пиениці озимої сорту Оберіг Миронівський залежно від позакореневого підживлення мікродобривами

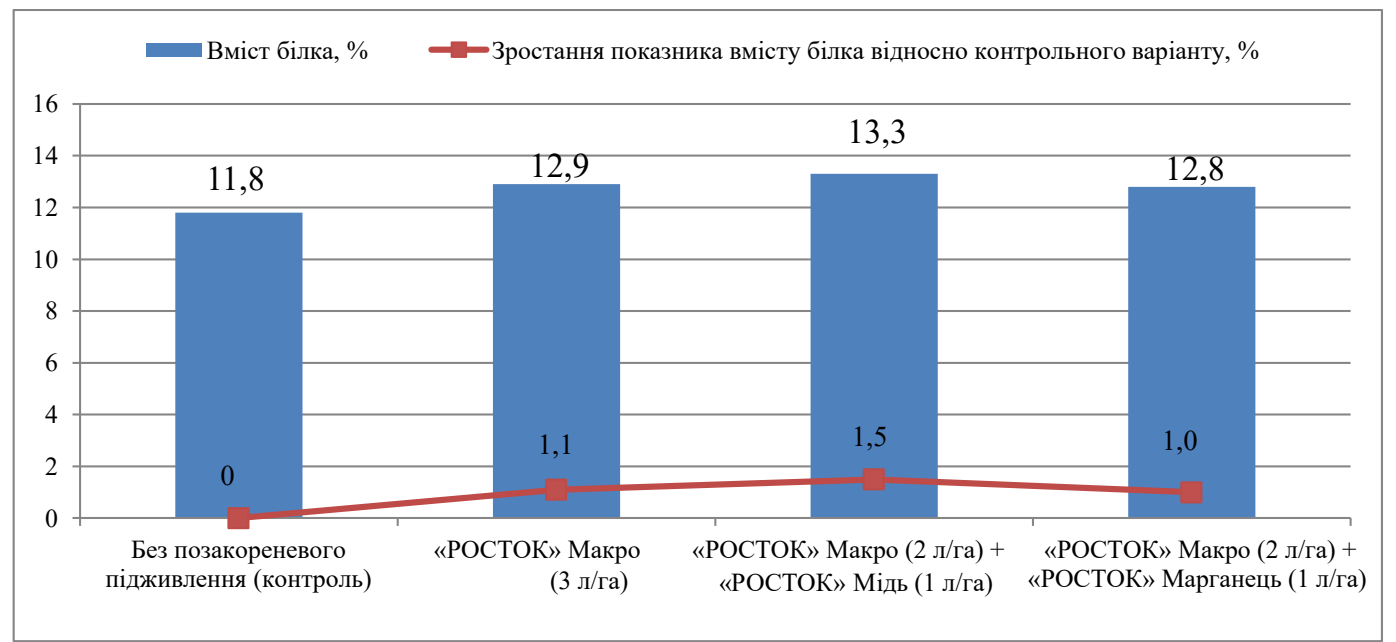

Рис. 2. Динаміка вмісту білка в зерні пшениці озимої сорту Оберіа Миронівський залежно від позакореневого підживлення мікродобривами 
Таблиця 4 - Вміст та якість клейковини в зерні пшениці озимої залежно від позакореневого підживлення мікродобривами (середнє за 2019-2020 рр.)

\begin{tabular}{|c|c|c|c|c|c|c|}
\hline \multirow[b]{2}{*}{ Варіанти досліду } & \multirow{2}{*}{$\begin{array}{c}\text { Вміст } \\
\text { сирої } \\
\text { клейковини, } \\
\%\end{array}$} & \multicolumn{2}{|c|}{ 士 до контролю } & \multirow{2}{*}{$\begin{array}{c}\text { Якість } \\
\text { клейковини, } \\
\text { од. пр. ВДК }\end{array}$} & \multicolumn{2}{|c|}{ \pm до контролю } \\
\hline & & 。융 & 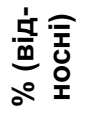 & & $\begin{array}{l}\text { 官 돔 } \\
\text { 덩 }\end{array}$ & 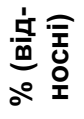 \\
\hline Без позакореневого підживлення (контроль) & 22,5 & 0 & 100 & 85 & 0 & 100 \\
\hline «РОСТОК» Макро (3 л/га) & 25,1 & 2,6 & 112 & 75 & -10 & 88 \\
\hline «РОСТОК» Макро (2 л/га) + «РОСТОК» Мідь (1 л/га) & 26,2 & 3,7 & 116 & 70 & -15 & 82 \\
\hline «РОСТОК» Макро (2 л/га) + «РОСТОК» Марганець (1 л/га) & 24,9 & 2,4 & 111 & 75 & -10 & 88 \\
\hline Середнє по досліду & 24,7 & - & - & 76 & - & - \\
\hline $\mathrm{HIP}_{05}$ & - & 1,6 & - & - & 7 & - \\
\hline
\end{tabular}

Внесення мікродобрив сприяло зростанню вмісту білка від 1,0\% до 1,5\% залежно від досліджуваного варіанта. Знову найбільш суттєве зростання показника відзначено у варіанті позакореневого підживлення посівів за схемою «РОСТОК» Макро (2 л/га) + «РОСТОК» Мідь (1 л/га), а саме на 1,5\%. Майже однакові показники вмісту білка були у варіантах підживлення «РОСТОК» Макро (3 л/га) та «РОСТОК» Макро (2 л/га) + «РОСТОК» Марганець (1 л/га). Загалом позакореневе підживлення посівів пшениці озимої мікродобривами за показником вмісту білка сприяло зростанню якості, а саме з третього до другого класу якості.

Математична обробка показників зміни вмісту білка методом дисперсійного аналізу виявила статистично значущий вплив на досліджуваний показник варіантів позакореневого підживлення мікродобривами: $\mathrm{Fp}=161,00>$ Fкрит $=6,59$.

Важливими технологічними показниками, які безпосередньо впливають на якість хлібобулочних виробів, $€$ вміст клейковини та ії якість.

Так, зерно пшениці озимої, вирощене в контрольному варіанті (без позакореневого підживлення), мало вміст клейковини, наближений до середнього значення, та якість клейковини II групи (задовільно слабка). За позакореневого підживлення рослин мікродобривами відбулося суттєве зростання показника вмісту клейковини в зерні (при $\left.\mathrm{HIP}_{05}=1,6 \%\right)$. Так, у варіанті «РОСТОК» Макро (2 л/га) + «РОСТОК» Мідь (1 л/га) вміст клейковини зростав на 3,7\%, дещо менше у варіантах «РОСТОК» Макро (3 л/га), а саме на 2,6\%, та «РОСТОК» Макро (2 л/га) + «РОСТОК» Марганець (1 л/га), а саме на 2,4\% порівняно з контролем (табл. 4). Слід відзначити, що різниця між досліджуваними варіантами позакореневого підживлення була несуттєвою.

Як показали результати наших досліджень, позакореневе підживлення рослин суттєво вплинуло на показник якості клейковини (HIP $05=7)$. Зменшення показника, що в цьому разі $€$ позитивним, відбулося у всіх досліджуваних нами варіантах підживлення на 10-15 од. пр. ВДК. Зерно, вирощене у варіанті позакореневого підживлення «РОСТОК» Макро (2 л/га) + «РОСТОК» Мідь (1 л/га), маючи показник 70 од. пр. ВДК, характеризувалося клейковиною найкращої I групи якості. Зерно двох інших варіантів за якістю клейковини перебувало на межі між II та I групами.
Покращення як кількісних, так і якісних показників клейковини зерна пшениці озимої сорту Оберіг Миронівський у всіх досліджуваних варіантах підживлення дасть змогу отримати якісну сировину для переробки на борошно та хлібобулочні вироби. Одночасно зростання якості зерна забезпечить вищу реалізаційну ціну та прибутковість виробництва.

Дисперсійний аналіз встановив статично значущий вплив позакореневого підживлення мікродобривами на кількість та якість клейковини зерна пшениці озимої. Особливо вагомим був вплив мікродобрив на вміст клейковини: $\mathrm{Fp}=566,24>$ Fкрит $=6,59$, значно меншим на якість клейковини: $\mathrm{Fp}=17,00>$ Fкрит $=6,59$.

Висновки. Результати експериментальних досліджень щодо виявлення впливу позакореневого підживлення хелатними мікродобривами на формування врожайності та якості зерна пшениці м'якої озимої підтвердили доцільність їх проведення.

Встановлено, що найвищий рівень урожайності був сфрормований сортом Оберіг Миронівський у варіанті позакореневого підживлення «РОСТОК» Макро (2 л/га) + «РОСТОК» Мідь (1 л/га) і склав 4,31 т/га, що на 0,62 т/га, або $16,8 \%$, більше, ніж на контролі.

Застосування мікродобрив «РОСТОК» Макро, «РОСТОК» Мідь та «РОСТОК» Марганець сприяло підвищенню якісних показників зерна пшениці озимої, що дає змогу отримувати якісну сировину для переробки на борошно та хлібобулочні вироби.

Позакореневе підживлення рослин пшениці озимої мікродобривами привело до збільшення показників склоподібності, вмісту білка та клейковини, що зумовило зростання якості зерна (з третього до другого класу). Вища якість зерна пшениці здатна забезпечити вищу реалізаційну ціну та прибутковість виробництва.

Найкращим за усіма технологічними показниками якості було зерно пшениці озимої, отримане у варіанті позакореневого підживлення «РОСТОК» Макро (2 л/га) + «РОСТОК» Мідь (1 л/га).

\section{СПИСОК ВИКОРИСТАНОЇ ЛІТЕРАТУРИ:}

1. Коломієць Л.А. Формування адаптивних ознак між сортовими гібридами озимої пшениці. Сортовивчення та охорона прав на сорти рослин. 2007. № 6. С. 26-34.

2. Голик Л.М. Новий зимостійкий сорт пшениці м'якої озимої (Triticum aestivum) Волошкова. Сортовивчення та охорона прав на сорти рослин. 2007. № 6. С. 5-11. 
3. Господаренко Г.М. Основи інтегрованого застосування добрив. Київ : ЗАТ НІЧЛАВА, 2002. 344 с.

4. Моргун В.В., Санін Є.Ю., Швартау В.В. Клуб 100 центнерів. Сучасні сорти та системи живлення і захисту озимої пшениці. Київ : Логос, 2014. 148 с.

5. Сайко В.Ф. Перспектива виробництва зерна в Україні. Вісник аграрної науки. 1997. № 9. С. 27-32.

6. Майданюк В.В. Урожайність та якість пшениці озимої у Північному Лісостепу залежно від технології вирощування. Збірник наукових праць ННЦ «/нститут землеробства НАAН». 2011. Вип. 1-2. С. 103-108.

7. Гошко В.В. Микроэлементы для пшеницы. Зерно. 2006. № 11. С. 53-56.

8. Булигін С.Ю. та ін. Мікроелементи в сільському господарстві. 3-тє вид. доп. Дніпропетровськ : Січ, 2007. $100 \mathrm{c}$.

9. Гончаренко Е.В., Кутолей Д.М., Полянчиков С.С. Обзор рынка хелатных микроудобрений. Агроном. 2007. № 1. C. 34-39.

10. Жемела Г.П., Мусатов А.Г. Агротехнічні основи підвищення якості зерна. Київ : Урожай, 1989. 160 с.

11. Санін Ю.В., Санін В.А., Санін О.Ю. Особливості позакореневого підживлення с/г культур мікроелементами. Агроном. 2016. № 4. С. 36-38.

12. Кудря С.І, Георгиця Я.І. Сумісна дія попередників і мікродобрив на продуктивність пшениці озимої в лівобережному Лісостепу України. Бюлетень /нституту зернового господарства. 2010. Вип. 39. С. 113-115.

13. Шакалій С.М. Якість зерна пшениці м'якої озимої за використання позакореневого підживлення в умовах лівобережного Лісостепу України. Нубіп. 2017. № 1. C. 76-84. URL: http://journals.nubip.edu.ua/index. php/Dopovidi/article/view/dopovidi2017.01.007/7755. DOI: http://dx.doi.org/10.31548/dopovidi2017.01.007.

14. Полянчиков С.П. Роль микроудобрений Реаком в повышении качества продукции. Посібник хлібороба. 2009. С. 37-39.

15. Бикін А.В. та ін. Роль оптимізації живлення та удобрення пшениці озимої шляхом позакореневого підживлення на фоні твердих добрив у підвищенні якості зерна, борошна і хліба в умовах правобережного Лісостепу України. Науковий вісник Національного університету біоресурсів і природокористування України. 2010. Вип. 149. С. 96-108.

16. Кутова А.М. Ефективність мікродобрив за різних рівнів удобрення сільськогосподарських культур на чорноземі опідзоленому Лівобережного Лісостепу : автореф. дис. ... канд. с.-г. наук : спец. 06.01.04. Харків, 2012. 24 c.

17. Лихочвор В.В. Мінеральні добрива та їх застосування. Львів : НВФ «Українські технології», 2008. 312 с.

18. Доспехов Б.А. Методика полевого опыта. Москва : Агропромиздат, 1985. 351 с.

19. Панфілова А.В., Гамаюнова В.В. Продуктивність сортів пшениці озимої залежно від фону живлення в умовах Південного Степу України. Науковий вісник Національного університету біоресурсів і природокористування України. 2018. Вип. 294. С. 129-136.

20. Вожегова Р.А., Мунтян Л.В. Вплив різних доз азотного добрива та норм висіву на елементи структури врожаю сортів пшениці озимої. Вісник аграрної науки Причорномор'я. 2015. Вип. 3. С. 107-115.

21. Генгало О.М., Генгало Н.О., Шеіна Є.В. Порівняльна оцінка різних видів азотних добрив за ранньо-вес- няного внесення на лучно-чорноземному ґрунті. Науковий вісник Національного університету біоресурсів і природокористування України. 2018. Вип. 286. С. 251-259.

\section{REFERENCES:}

1. Kolomiets, L.A. (2007). Formuvannya adaptivnikh oznak mizh sortovimi gibridami ozimoï pshenitsi [Formation of adaptive traits sn winter wheat intraspecific hybrids (Triticum aestivum L.)]. Plant Varieties Studying and Protection, 6, 26-34 [in Ukrainian].

2. Golik, L.M. (2007). Noviy zimostiykiy sort pshenitsi m'yakoï ozimoï (Triticum aestivum) Voloshkova [New winter hardy winter bread wheat cultivar (Triticum aestivum L.) Voloshkova ]. Plant Varieties Studying and Protection, 6, 5-11 [in Ukrainian].

3. Gospodarenko, G.M. (2002). Osnovi integrovanogo zastosuvannya dobriv [Fundamentals of integrated fertilizer application]. Kyiv : ZAT NIChLAVA [in Ukrainian].

4. Morgun, V.V., Sanin, Ye.Yu., Shvartau, V.V. (2014) Klub 100 tsentneriv. Suchasni sorti ta sistemi zhivlennya i zakhistu ozimoï pshenitsi [Club of 100 quintals. Modern varieties and systems of nutrition and protection of winter wheat]. Kyiv : LOGOS [in Ukrainian].

5. Sayko, V.F. (1997). Perspektiva virobnitstva zerna v Ukraïni [Perspective for grain production in Ukraine]. Bulletin of Agricultural Science, 9, 27-32 [in Ukrainian].

6. Maydanyuk, V.V. (2011). Urozhaynist ta yakist pshenitsi ozimoï u Pivnichnomu Lisostepu zalezhno vid tekhnologiï viroshchuvannya [Yield and quality of winter wheat in the Northern Forest-Steppe depending on the cultivation technology]. Collection of scientific works of the National Scientific Center "Institute of Agriculture of NAAS", 1-2, 103-108 [in Ukrainian].

7. Goshko, V.V. (2006). Mikroelementy dlya pshenitsy [Trace elements for wheat]. Grain, 11, 53-56 [in Ukrainian].

8. Bulygin, S.Yu. at al. (2007). Mikroelementi v silskomu gospodarstvi [Trace elements in agriculture. 3rd type. ext.]. Dnipropetrovsk : SICH [in Ukrainian].

9. Goncharenko, Ye.V., Kutoley, D.M., Polyanchikov, S.S. (2007). Obzor rynka khelatnykh mikroudobreniy [Market overview of chelated microfertilizers]. Agronomist, 1, 34-39 [in Russian].

10. Zhemela, G.P., Musatov, A.G. (1989). Agrotekhnichni osnovi pidvishchennya yakosti zerna [Agrotechnical bases of grain quality improvement]. Kyiv : UROZHAY [in Ukrainian].

11. Sanin, Yu.V., Sanin, V.A., Sanin, O.Yu. (2016). Osoblivosti pozakorenevogo pidzhivlennya s/g kultur mikroelementami [Features of foliar feeding of agricultural crops with microelements]. Agronomist, 4, 36-38 [in Ukrainian].

12. Kudrya, S.I, Georgitsya, Ya.I. (2010). Sumisna diya poperednikiv i mikrodobriv na produktivnist pshenitsi ozimoï v livoberezhnomu Lisostepu Ukraïni [Combined effect of precursors and microfertilizers on the productivity of winter wheat in the forest-steppe of Ukraine]. Bulletin of the Institute of Agriculture, 39, 113-115 [in Ukrainian].

13. Shakaliy, S.M. (2017). Yakist zerna pshenitsi m'yakoï ozimoï za vikoristannya pozakorenevogo pidzhivlennya v umovakh livoberezhnogo Lisostepu Ukraïni [Grain quality of soft winter wheat using foliar fertilization in the 
conditions of the left-bank Forest-Steppe of Ukraine]. Scientific reports of NULES of Ukraine, 1, URL: http:// journals.nubip.edu.ua/index.php/Dopovidi/article/view/ dopovidi2017.01.007/7755. [in Ukrainian].

14. Polyanchikov, S.P. (2009). Rol mikroudobreniy Reakom $\checkmark$ povyshenii kachestva produktsii [The role of Reakom microfertilizers in improving product quality]. Farmer's manual, 37-39 [in Ukrainian].

15. Bikin, A.V. at al. (2010). Rol optimizatsij zhivlennya ta udobrennya pshenitsi ozimoj shlyakhom pozakorenevogo pidzhivlennya na foni tverdikh dobriv u pidvishchenni yakosti zerna, boroshna i khliba $v$ umovakh pravoberezhnogo Lisostepu Ukrajni [The role of optimization of nutrition and fertilization of winter wheat by foliar fertilization against the background of solid fertilizers in improving the quality of grain, flour and bread in the right-bank forest-steppe of Ukraine]. Scientific Bulletin of the National University of Life and Environmental Sciences of Ukraine, 149, 96-108 [in Ukrainian].

16. Kutova, A.M. (2013). Yefektivnist mikrodobriv za riznikh rivniv udobrennya silskogospodarskikh kultur na chornozemi opidzolenomu Livoberezhnogo Lisostepu [Efficiency of microfertilizers at different levels of fertilization of agricultural crops on Forest-Steppe] Extended abstract of candidate's thesis. Kharkiv : NNC Institute for Soil Science and Agrochemistry Research named after O.N. Sokolovsky [in Ukrainian].

17. Likhochvor, V.V. (2008). Mineralni dobriva ta ikh zastosuvannya [Mineral fertilizers and their application]. Lviv : Scientific and Production Enterprise "Ukrainian Technologies" [in Ukrainian].

18. Dospekhov, B.A. (1985). Metodika polevogo opyta [Methods of field experience]. Moskva : AGROPROMIZDAT [in Russian].

19. Panfilova, A.V., Gamayunova, V.V. (2018). Produktivnist sortiv pshenitsi ozimoï zalezhno vid fonu zhivlennya v umovakh Pivdennogo Stepu Ukraïni [Productivity of winter wheat varieties depending on the feeding background in the conditions of the Southern Steppe of Ukraine]. Scientific Bulletin of the National University of Life and Environmental Sciences of Ukraine, 294, 129-136 [in Ukrainian].

20. Vozhegova, R.A., Muntyan, L.V. (2015). Vpliv riznikh doz azotnogo dobriva ta norm visivu na elementi strukturi vrozhayu sortiv pshenitsi ozimoï [Influence of different doses of nitrogen fertilizer and seeding rates on the elements of the yield structure of winter wheat varieties]. Ukrainian Black Sea region agrarian science, 3, 107-115 [in Ukrainian].

21. Gengalo, O.M., Gengalo, N.O., Sheina, E.V. (2018). Porivnyalna otsinka riznikh vidiv azotnikh dobriv za ranno-vesnyanogo vnesennya na luchno-chornozemnomu grunti [Comparative evaluation of different types of nitrogen fertilizers for early spring application on meadow- black soil]. Scientific Bulletin of the National University of Life and Environmental Sciences of Ukraine, 286, 251-259 [in Ukrainian].

Ямковий В.Ю., Буняк О.І., Ящук Н.О. Продуктивність та якість зерна пшениці озимої залежно від позакореневого підживлення в лівобережному Лісостепу України

Мета. Метою статті $€$ встановлення особливостей формування врожайності та якості зерна пшениці м'якої озимої залежно від позакореневого підживлення хелатними мікродобривами в умовах лівобережного Лісостепу України. Методи дослідження - польові, лабораторні, статистичні. Планування, проведення польових дослідів, спостереження й обліки здійснювали за Б.О. Доспєховим. Статистичні опрацювання результатів дослідів проводили дисперсійним методом, використовували пакети прикладних програм Agrostat, Microsoft Excel.

Результати. Встановлено, що формування елементів структури врожайності значною мірою залежить від проведення позакореневого підживлення. Зокрема, було виявлено збільшення кількості зерен у колосі на 3,3-5,3 зерен, зростання маси зерна з колосу на 0,22-0,33 г та маси 1000 зерен на 3,1-4,9 г залежно від варіанта позакореневого підживлення. Найвищі показники елементів структури врожаю сформувалися у варіанті позакореневого підживлення рослин «РОСТОК» Макро (2 л/га) + «РОСТОК» Мідь (1 л/га).

Застосування різних варіантів позакореневого підживлення під час вирощування пшениці озимої сприяло доброму розвитку рослин протягом всієї вегетації, що дало змогу сфрормувати врожайність, яка значно перевищила контрольний варіант.

Внесення комплексного добрива «РОСТОК» Макро в дозі 3 л/га забезпечило збільшення приросту зерна на 0,36 т/га порівняно з контролем. Застосування добрива «РОСТОК» Макро в дозі 2 л/га разом із монодобривом «РОСТОК» Марганець в дозі 1 л/га підвищило приріст зерна на 0,45 т/га. Найвищий приріст зерна отримано у варіанті позакореневого підживлення рослин добривами «РОСТОК» Макро (2 л/га) + «РОСТОК» Мідь (1 л/га), а саме 0,62 т/га.

3'ясовано, що проведення позакореневого підживлення сприяло підвищенню технологічних показників (склоподібності, вмісту білка, кількості та якості клейковини) та зростанню класу якості зерна пшениці озимої. Найкращим за усіма технологічними показниками якості було зерно пшениці озимої, отримане у варіанті позакореневого підживлення «РОСТОК» Макро (2 л/га) + «РОСТОК» Мідь (1 л/га).

Висновки. В умовах лівобережного Лісостепу України на чорноземі глибокому малогумусному суттєвий вплив на збільшення урожайності та якості зерна пшениці озимої має позакореневе підживлення мікродобривами. Варіант «РОСТОК» Макро (2 л/га) + «РОСТОК» Мідь (1 л/га) забезпечив максимальну врожайність разом із високими показниками якості зерна пшениці озимої.

Ключові слова: пшениця озима, хелатні мікродобрива, живлення рослин, структура врожаю, урожайність зерна, склоподібність зерна, вміст та якість клейковини, вміст білка, клас зерна.

Yamkoviy V.Yu., Bunyak O.I., Yashchuk N.O. Productivity and quality of winter wheat grains depending on the foliar feeding fertilization with micronutrients in the left bank Forest-Steppe of Ukraine

Purpose. To establish the peculiarities of yield formation and grain quality of soft winter wheat depending on foliar feeding with chelated microfertilizers in the conditions of the left bank Forest-Steppe of Ukraine.

Research methods - field, laboratory and statistical. Planning, conducting field experiments, observations and records were carried out according to B.O. Dospekhov. 
Statistical processing of the results of the experiments was carried out using the dispersion method, using software packages Agrostat, Microsoft Excel.

Results. It is established that the formation of the elements of the yield structure largely depends on foliar feeding. In particular, an increase in the number of grains in an ear was found by 3.3-5.3 grains, grain weight per ear $-0.22-0.33 \mathrm{~g}$ and 1000 grain weight per ear - 3.1-4.9 $\mathrm{g}$ depending on the option of foliar feeding. Highest rates of yield structure elements formed in the variant of foliar feeding of plants "ROSTOK" Macro (2 l/ha) + "ROSTOK" Copper (1 l/ha).

The use of various variants for foliar feeding when growing winter wheat, it promoted the good development of plants throughout the growing season, which made it possible to form yield, which significantly exceeded the performance of the control variant.

The application of the complex fertilizer "ROSTOK" Macro at a dose of $3 \mathrm{l} / \mathrm{ha}$ provided an increase in grain growth by $0.36 \mathrm{t} / \mathrm{ha}$ in comparison with the control. The use of the "ROSTOK" Macro fertilizer at a dose of $2 \mathrm{l} / \mathrm{ha}$ in combination with the mono-fertilizer "ROSTOK" Manganese at a dose of $1 \mathrm{l} /$ ha increased the grain growth by $0.45 \mathrm{t} / \mathrm{ha}$. The highest grain growth was obtained in the variant of foliar feeding of plants with fertilizers "ROSTOK" Macro (2 l/ha) + "ROSTOK" Copper (1 l/ha) - 0.62 t/ha.

Established that carrying out foliar feeding contributed to an increase in technological indicators (vitreousness, protein content, quantity and quality of gluten) and an increase in the quality class of winter wheat grain. The best in all technological quality indicators was winter wheat grain obtained in the variant of foliar feeding "ROSTOK" Macro (2 l/ha) + "ROSTOK" Copper ( $1 \mathrm{l} / \mathrm{ha})$.

Conclusions. In the conditions of the left-bank foreststeppe of Ukraine on deep low-humus chernozem, foliar feeding with micronutrient fertilizers has a significant effect on increasing the yield and quality of winter wheat grain. Option "ROSTOK" Macro (2 I/ha) + "ROSTOK" Copper ( $1 \mathrm{l} / \mathrm{ha}$ ) provided the maximum yield, in combination with high quality indicators of winter wheat grain.

Key words: winter wheat, chelated microfertilizers, plant nutrition, the yield structure, grain yield, vitreousness grain, content and quality of gluten, protein content, grain grade. 